\title{
Occurrence of gastrointestinal parasites in slaughter rabbits
}

\author{
Krzysztof Szkucik • Renata Pyz-Łukasik • \\ Klaudiusz Oktawian Szczepaniak • Waldemar Paszkiewicz
}

Received: 17 July 2013 / Accepted: 24 September 2013 / Published online: 8 October 2013

(C) The Author(s) 2013. This article is published with open access at Springerlink.com

\begin{abstract}
The aim of the study was to determine the occurrence of gastrointestinal parasites in slaughter rabbits managed in small scale farms and under industrial farming system. The research material included intestines and livers of rabbits slaughtered between years 2007 and 2011. The rabbit carcasses submitted to parasitological examination had passed the sanitary veterinary inspection as fit for human consumption. The samples were collected in spring and autumn seasons. The studies showed no effect of a rabbit farming system, season of the year, or differences in an invasion type in each year. The parasitological test recognized exclusively mixed infestation diagnosed in $79.56 \%$ of the studied animals. Parasitological evaluation of the rabbit internal organs identified the invasions of coccidia ( $78.83 \%)$, nematoda $(16.42 \%)$, cestoda $(0.72 \%)$, and cysticerci Cysticercus pisiformis $(4.74 \%)$. Coccidian invasions found in intestines were dominant, and their prevalence reached $56.48 \%$, while the hepatic coccidian extensity was markedly lower, i.e., $3.34 \%$ of the examined rabbits. Invasions were characterized by low intensity. The studies recognized invasions of nematoda (Obeliscoides cuniculi, Graphidium strigosum, Trichostrongylus sp., Strongyloides sp., Passalurus ambiguus, Trichuris leporis), cestoda (Mosgovoyia pectinata), and cysticerci $C$. pisiformis .
\end{abstract}

\section{Introduction}

Edible slaughter raw materials obtained from slaughter animals have to satisfy the stringent food safety requirements. In order to ensure safety of muscle tissues and edible organs, the

K. Szkucik $\cdot$ R. Pyz-Lukasik $\cdot$ K. O. Szczepaniak $(\bowtie) \cdot$

W. Paszkiewicz

University of Life Sciences, Lublin, Poland

e-mail: k.o.szczepaniak@gmail.com appropriate conditions of slaughter and storage must be maintained, while morbid traits and qualitative deviations recognized at ante- and postmortem inspection carried out by official veterinarians (Szkucik and Paszkiewicz 2011). According to the reports of the General Veterinary Inspectorate (RRW-6 2007-2011, http://www.wetgiw.gov.pl/index.php? action=art\&a_id=4239), in the years 2007-2011 in Poland, $2,430,991$ rabbit carcasses underwent the postmortem examination. Morbid traits and qualitative deviations were reported in $1.3 \%$ of the evaluated carcasses, whereas $0.75 \%$ was considered unfit for consumption. Coccidiosis was the most often recognized postslaughter change, and it was diagnosed in 15,696 rabbit carcasses which constituted $48.3 \%$ of all cases with confirmed morbid traits or qualitative deviations. It was also a cause for sanitary condemnation of $4 \%$ (730 carcasses) of all carcasses declared unsuitable for consumption. These data indicate that eimerian infections have an enormous economic importance and often lead to huge losses in meat production. Even subclinical form of intestinal and liver coccidiosis may result to weight depression, diarrhea, and reduction of food absorbance and digestion which finally result in a decline in profitability of rabbit production (Al-Quraishy et al. 2012; Metwaly et al. 2013)

Other parasitic traits were found in 59 cases, i.e., $0.18 \%$ of carcasses with noticeable deviations. The carcasses were condemned as unfit for consumption and accounted for $0.3 \%$ rejection rate. Postmortem examination does not allow to verify the agent producing hepatic changes; therefore, although "coccidiosis" is recognized, there may have been different specific causes like other parasites or bacterial infections (Sadzikowski et al. 2008). However, compared to other species of domestic animals, a number of parasitic invasions in rabbits appear to be less risky than coccidian ones (Harrenstien 1999; Rinaldi et al. 2007). Under the commercial production conditions, cysticercosis was noted in $4.27 \%$ of rabbits intended for slaughter (Sołtysiak et al. 2007). 
The objective of the study was to determine occurrence of gastrointestinal parasites in slaughter rabbits obtained from small scale farms and industrial farming system.

\section{Material and methods}

The study material comprised intestines and livers of 274 rabbits managed in small scale farms and under commercial production system. The organs were randomly collected from the animals slaughtered between years 2007 and 2011 and the samples taken in spring and autumn seasons. The animal live body weight ranged between 3.8 and $5.5 \mathrm{~kg}$, and the rabbits were classified into first quality class according to the Polish norms. Contents and mucous membrane of the rabbit digestive tract were collected from the stomach, small intestine, and large intestine. The obtained material was evaluated through macroscopic analysis followed by decantation treatment. The recovered parasites were counted and fixed in alcohol with glycerin. A systematic position of the recovered parasites was determined analyzing the morphometric characteristics. The coccidian extensity (prevalence) was established examining the fecal samples (rectal swab) by flotation method. The extensity of Eimeria stiedae invasion was found using the technique of bile smear microscopy, while the invasion intensity of the Eimeria genus protozoa was assessed using McMaster chamber and expressed as the number of oocysts per gram (OPG index). Besides, during the necropsy procedure, anatompathological changes in the intestines and liver were noted.

\section{Results and discussion}

The rabbit carcasses and internal organs sampled for parasitological examination passed the sanitary veterinary inspection according to the Regulation of the European Parliament (Regulation (EC) no. 854/2004) and were considered fit for human consumption. The studies did not show the influence of a

Table 1 Results of parasitological and postmortem examinations of slaughter rabbits

\begin{tabular}{llcc}
\hline Animals examined & & $\begin{array}{l}\text { No. } \\
274\end{array}$ & $\begin{array}{l}\text { Percentage (\%) } \\
100\end{array}$ \\
\hline Pathological changes & Carcass & 0 & 0 \\
& Lungs & 0 & 0 \\
& Livers & 34 & 12.40 \\
& Intestines & 22 & 8.02 \\
Not infected & & 56 & 20.43 \\
Monoinvasion & & 0 & 0 \\
Mixed infestation & & 218 & 79.56 \\
\hline
\end{tabular}

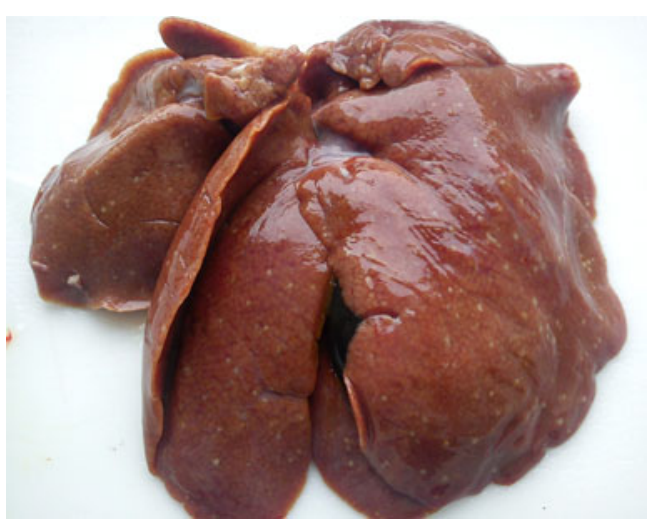

Fig. 1 Hepatic coccidiosis. Macroscopic changes in the liver during the invasion $E$. stiedae

rabbit management system or season of the year. Alike, no differences were reported in an invasion type, its intensity, or prevalence in each study year. Therefore, the obtained research results were discussed altogether. The macroscopic analysis of internal organs (Table 1) showed enlargement of some livers and morbid changes in the form of whitish or yellowish tubercles varying in size from that of a millet seed to a pea. Consequently, the organs were considered unsuitable for consumption (Fig. 1). The changes were detected in $12.4 \%$ of livers and $8 \%$ of intestines.

The parasitological evaluation of the collected material recognized solely mixed infestation (Figs. 2 and 3) identified in 218 animals, i.e., $79.56 \%$ of the studied rabbits. The rest of animals were parasite free. The detailed necropsy and parasitological findings of rabbits are presented in Table 2. The parasitological examination of 274 rabbit internal organs showed the invasion of coccidia in 216 animals (78.83\%), nematode in 45 animals (16.42\%), and cestode in 2 animals (0.72\%). The presence of cysticerci Cysticercus pisiformis was confirmed in 13 rabbits (4.74 \%) (Figs. 4 and 5).

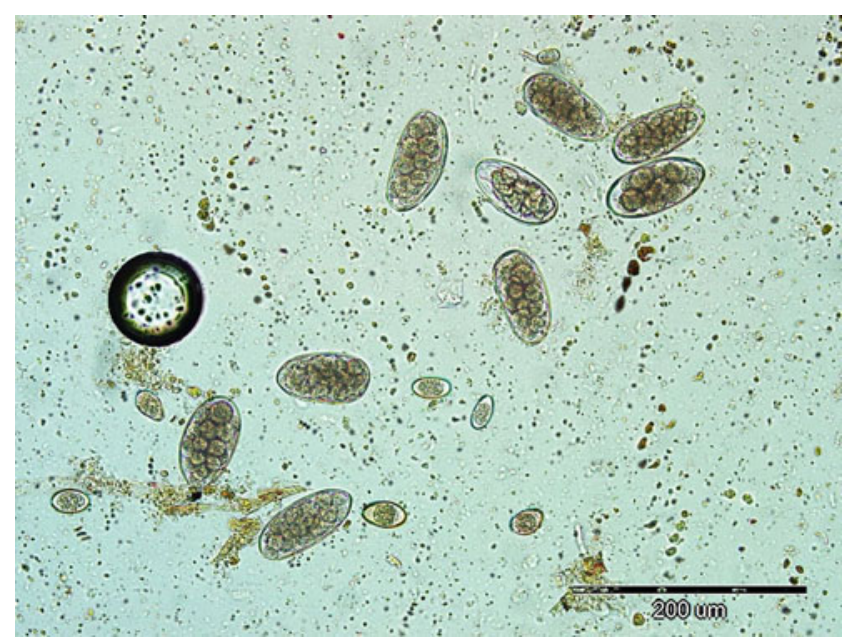

Fig. 2 Mixed infestation. Oocysts of Eimeria spp. and eggs of nematodes from genus Trichostrongylus. Flotation method 


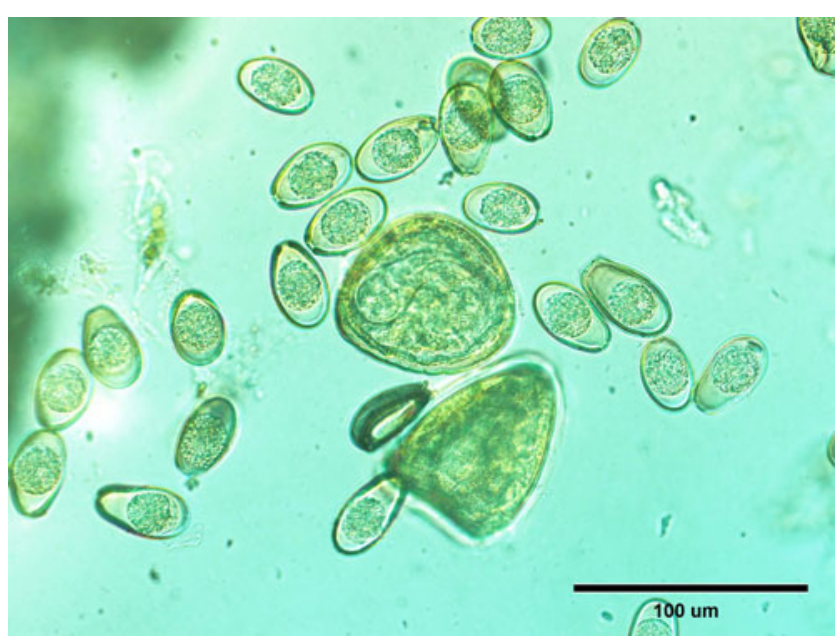

Fig. 3 Mixed infestation. Oocysts of Eimeria spp. and eggs of cestodes M. pectinata. Flotation method

The detailed results on prevalence of intestinal and hepatic coccidiosis as well as the invasion intensity expressed as the number of OPG of feces from the infected rabbits are summarized in Table 2.

In the animals under investigation, dominant coccidian invasions located in intestines were detected; their extensity reached $56.48 \%$. Whereas, there was reported substantially lower prevalence of hepatic coccidia determined in $3.34 \%$ of the examined rabbits. The aforementioned invasions were characterized by relatively low intensity that averaged between 1,440 and 64,358 OPG. A great discrepancy in the number of oocysts per gram of feces was stated a range from $10^{2}$ to over $10^{6}$.

According to available knowledge, coccidiosis proves to be one of major parasitic diseases in rabbits. Previous study (Pakandl et al. 2008; Papeschi et al. 2013) showed that the

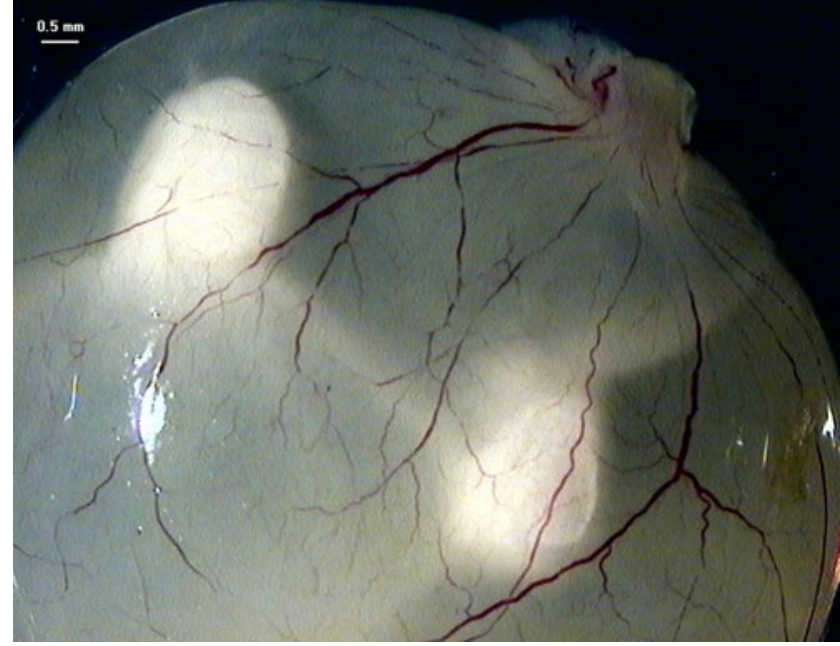

Fig. 4 Cysticercus of T. pisiformis

number of oocysts shedding in feces is correlated to the intensity of invasion, age, and immune status of animals. Oocyst shedding pattern also depends on sex and physiological condition. High oocyst production is usually not reached before weaning (Pakandl and Hlásková 2007). Subsequently, oocyst excretion gradually increases and peaks between 46th and 53rd day of age (Papeschi et al. 2013). Female rabbits used for reproduction are observed two peaks of oocyst excretion after parturition (Połozowski 1993). These factors could play a critical role in the results that we have obtained.

The invasion prevalence depends on animal age, management system as well preventive and therapeutic strategies applied. Coccidian of the genus Eimeria are common in young domestic animals during the suckling period. In contrast, the suckling rabbits cannot be infected (Pakandl and Hlásková 2007). Rabbits younger than 21 days are not
Table 2 Results of parasitological and necropsy examinations of slaughter rabbits

\begin{tabular}{llccl}
\hline Parasites & Found & $\begin{array}{l}\text { Number of } \\
\text { infected }\end{array}$ & Prevalence (\%) & $\begin{array}{l}\text { Intensity of invasion } \\
\text { (OPG/number of nematodes, } \\
\text { cestodes, and cysticercus) }\end{array}$ \\
\hline Coccidia & Hepatic coccidiosis & 7 & 3.34 & $18,614.28$ \\
& Intestinal coccidiosis & 122 & 56.48 & $6,940.16$ \\
& Mixed & 87 & 31.75 & $46,113.79$ \\
& Total & 216 & 91.57 & $71,668.23$ \\
Nematoda & Obeliscoides cuniculi & 1 & 0.36 & 1 \\
& Graphidium strigosum & 3 & 1.09 & 3.33 \\
& Trichostrongylus spp. & 15 & 5.47 & 19.73 \\
& Trichuris leporis & 10 & 3.64 & 27.10 \\
& Passalurus ambiguus & 16 & 5.83 & 16.21 \\
& Total & 45 & 16.39 & 67.37 \\
Cestoda & Mosgovoyia pectinata & 2 & 0.72 & 6.0 \\
& Cysticercus pisiformis & 13 & 4.74 & 18.0 \\
& Total & 15 & 5.46 & 24
\end{tabular}




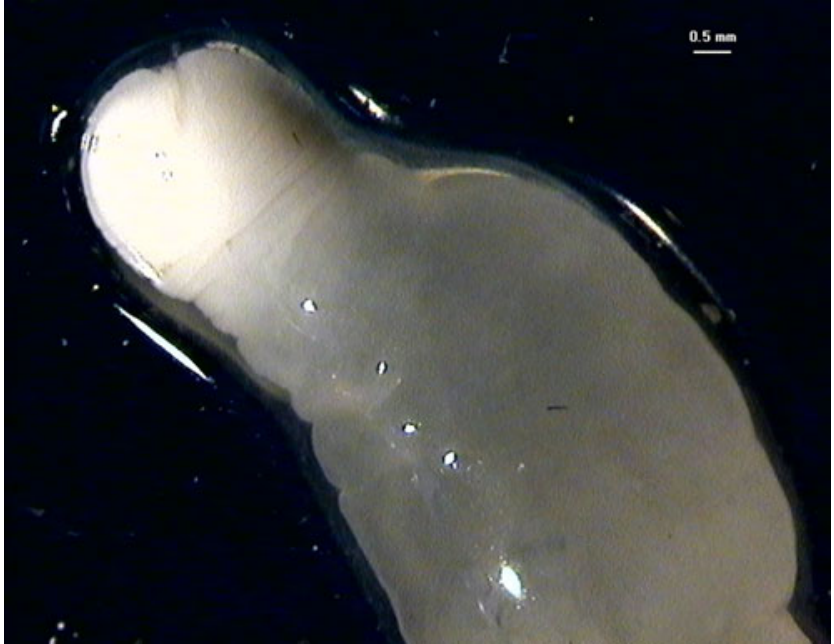

Fig. 5 Invaginated scolex from cysticercus of T. pisiformis

susceptible to natural infection with coccidian, and according to the recent study (Pakandl and Hlásková 2007), younger than 19 days could not be infected with intestinal species Eimeria intestinalis and Eimeria flavescens. Despite these facts, this infection affects mainly young rabbits before first year of life. Kits are more frequently infected from around 5 to the 6 weeks of age to around 3 months of age (GomezBautista et al. 1987). In our study, rabbits were around 8 months of age.

The research data indicate that the highest share of infected rabbits ( 95.8 up to $100 \%$ ) is determined in animals from the rabbit farms (Balicka-Ramisz 1999; Sadzikowski et al. 2008). An excessive stocking density of animals reported in the extensive management system favor invasion mechanisms. Markedly lower extensity of coccidiosis from $8.33 \%$ up to $51 \%$ was found in rabbits living in the wild (Foronda et al. 2005; Yagoob and Hossein 2011). In the case of farmed rabbits, the invasions of following intestinal coccidia

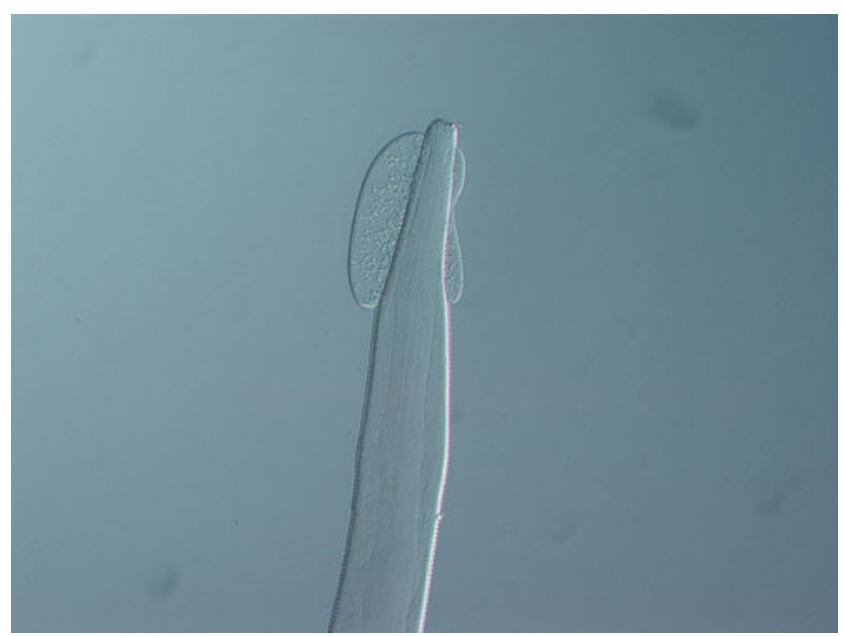

Fig. 6 Anterior portion of Trichostrongylus sp.

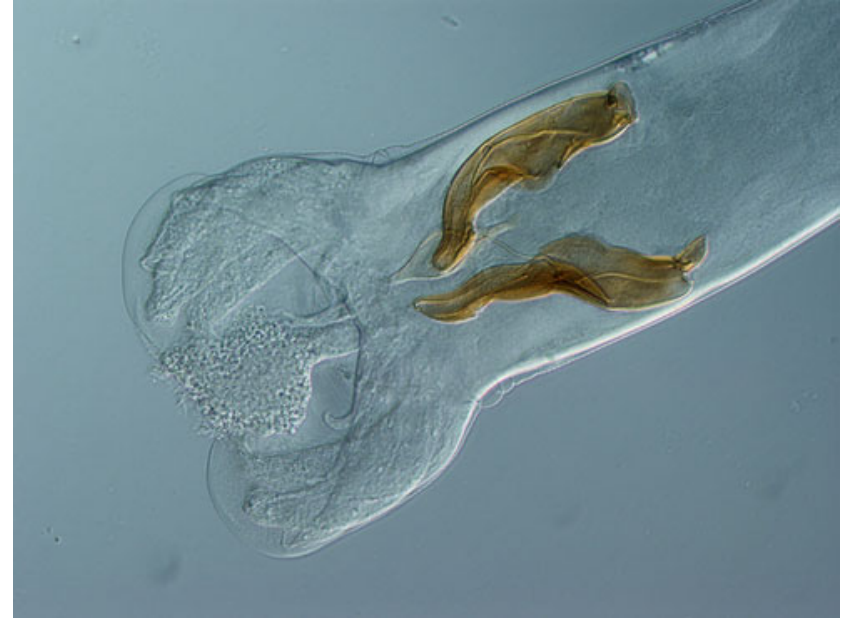

Fig. 7 Bursa copulatrix in male of Trichostrongylus sp.

predominated (6.7-96.6 \%): E. pisiformis, Eimeria media, Eimeria perforans, E. intestinalis, Eimeria magna, Eimeria coecicola, E. flavescens, and Eimeria irresidua. Infection rate with $E$. stiedae (hepatic coccidiosis) was considerable as, subject to a raising system, the coccidia oocysts were detected in 16-53\% of the examined animals (BalickaRamisz 1999; Boag et al. 2001). The parasitological study of farmed rabbit feces displayed multiple species invasion of coccidian (E. stiedae, E. media, E. perforans, and E. magna) in $70 \%$ (basic stock) and $85 \%$ (juveniles) of the examined samples (Nosal et al. 2006). As for wild rabbits, intestinal invasion by E. magna (5\%) and hepatic by $E$. stiedae $(3.33 \%)$ were recognized (Yagoob and Hossein 2011). Twelve species of coccidia have been reported to affect the rabbit of Sylvilagus genus worldwide and 14 species of the rabbit genus Oryctolagus. All of them belong to Eimeria genus, and only two of them were isolated in the representatives of both genera of rabbits (Eimeria neoleporis and $E$. stiedae) (Duszynski et al. 1999).

Coccidia species occurring in rabbits vary in terms of pathogenicity. The most pathogenic coccidia prove to be $E$. flavescens and $E$. intestinalis that are responsible for acute diarrhea and animal mortality. It was shown that the clinical course of rabbit coccidiosis was also observed to follow $E$. stiedae invasion. Relatively, low pathogenicity is attributed to E. coecicola, Eimeria exigua, E. perforans, and Eimeria vejdovsky which are frequently identified in asymptomatic rabbits (AL-Naimi et al. 2012; Darzi et al. 2007; Pakandl 2009). It was previously stated that in rabbits from cuniculture dominate mixed coccidian invasions. A total number of nine species of Eimeria spp. were found in the industrial farm from Poland which showed our previous study (Sadzikowski et al. 2008). These infections usually lead to clinical coccidiosis primarily in kits. Typical clinical signs of this disease include diarrhea, anemia, dehydration, failure to gain weight, and growth retardation (Pakandl 2009). Adult rabbits are mostly 


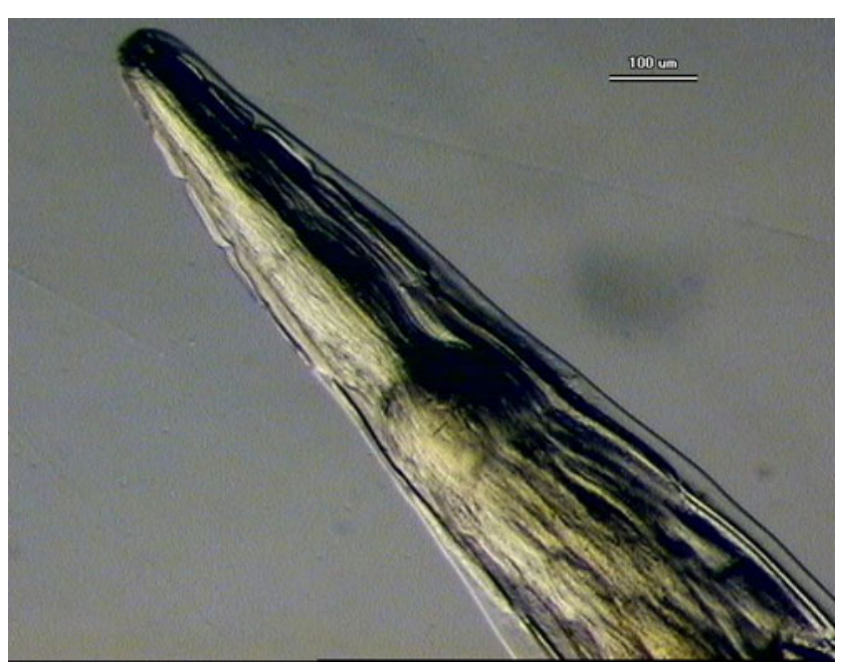

Fig 8 Anterior portion of P. ambiguus

asymptomatic carriers; however, the analysis of Veterinary Inspection reports (RRW-6 2007-2011) showed that during the last years, rabbit coccidiosis has been responsible for a great part of lesions diagnosed in slaughter houses.

The present studies have recognized invasion of nematodes: Obeliscoides cuniculi, Graphidium strigosum, Trichostrongylus spp. (Figs. 6 and 7), Strongyloides sp., Passalurus ambiguus (Figs 8 and 9), Trichuris leporis, cestodes Mosgovoyia pectinata, and cysticerci of $C$. pisiformis. The nematode invasion extensity ranged from $0.36 \%$ up to $5.83 \%$ that of cestode invasion- $0.72 \%$ and cysticerci $C$. pisiformis $-4.74 \%$. While the intensity of nematode invasion varied within 1 and 73 (average 3.33-27.1), cestode invasion from 5 up to 7 (average 6.0) and cysticerci C. pisiformis between 7 up to 28 (average 18.0). Nematodes, cestodes, and cysticerci $C$. pisiformis were recovered from the rabbits examined in 2007 and 2011, while only nematodes were isolated from the research material studied in 2010.

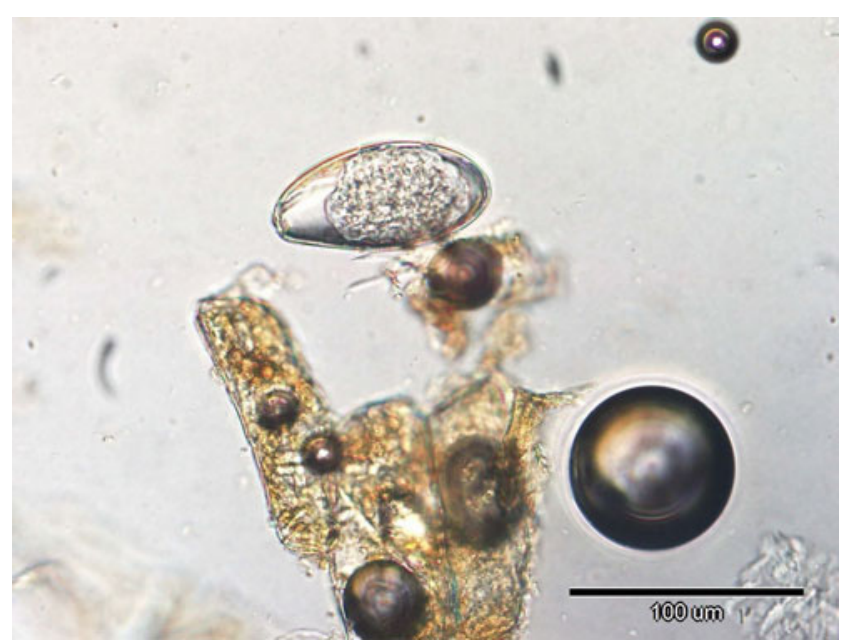

Fig. 9 Egg of Passalurus ambiguus. Flotation method
More professional literature addresses the problem of gastrointestinal parasites occurring in free living rabbits as compared to farmed ones (Boag 1985). The other authors' reports concerning parasitological evaluation of rabbits living in natural habitat highlight higher diversity of gastrointestinal parasite species as against rabbits under various management systems (Boag et al. 2001; Foronda et al. 2005). The observed prevalence of both nematode and cestode invasion in the population of rabbits living in the wild appeared to be higher than that established in the commercial rabbit rearing units. As for wild rabbit population, the highest invasion extensity was determined for Passalurus ambiguus (from $14.2 \%$ up to $78 \%$ ), Graphidium strigosum (32.8-78 \%), and Trichostrongylus retortaeformis (11-79\%). Considerably, lower prevalence was established for Andrya cuniculi invasion (11-26\%) and cestode Taenia pisiformis, Mosgovoyia ctenoides (26-43\% and 5-44\%, respectively) (Allan et al. 1999; Boag et al. 2001; Foronda et al. 2005). For farmed rabbits, a source of invasion is likely to be a population of undomesticated rabbits and hares that are hosts harboring the same species of cestode and nematode (Soveri and Valtonen 1983).

Farmed rabbits were most often infested by P. ambiguus whose prevalence varied with season of the year and animal age. The highest extensity $40 \%$ was established in the summer period. The parasite did not occur in young animals and in autumn season (Nosal et al. 2006).

The obtained research results have provided evidence for the importance of surveillance of slaughter rabbit parasitic diseases as well as implementation of appropriate preventive strategies. Parasitic invasions, especially coccidiosis, have prominent effect on animal overall performance and economic benefits of rabbit production. From the sanitary veterinary viewpoint, the invasions are determinants of the obtained slaughter material quantity and quality.

Open Access This article is distributed under the terms of the Creative Commons Attribution License which permits any use, distribution, and reproduction in any medium, provided the original author(s) and the source are credited.

\section{References}

Allan JC, Craig PS, Sherington J, Rogan MT, Storey DM, Heath S, Iball K (1999) Helminth parasites of the wild rabbit Oryctolagus cuniculus near Malham Tarn, Yorkshire, UK. J Helminthol 73: 289-294

AL-Naimi RAS, Khalaf OH, Tano SY, AL-Taee EH (2012) Pathological study of Hepatic coccidiosis in naturally infected rabbit. ALQadisiya. J Vet Med Sci 11:63-69

Al-Quraishy S, Metwaly MS, Dkhil MA, Abdel-Baki AA, Wunderlich F (2012) Liver response of rabbits to Eimeria coecicola infections. Parasitol Res 110:901-911 
Balicka-Ramisz A (1999) Wpływ kokcydiostatyków na przebieg kokcydiozy i efekty produkcyjne w przemysłowej fermie królików. Wiad Parazytol 45:193-198

Boag B (1985) The incidence of helminth parasites from the wild rabbit Oryctolagus cuniculus (L.) in Eastern Scotland. J Helminthol 59: 61-69

Boag B, Lello J, Fenton A, Tompkins DM, Hudson PJ (2001) Patterns of parasite aggregation in the wild European rabbit (Oryctolagus cuniculus). Int J Parasitol 31:1421-1428

Darzi MM, Mir MS, Kamil SA, Nashirudddullach N, Munshi ZH (2007) Pathological changes and local defense reaction occurring in spontaneous hepatic coccidiosis in rabbits (Oryctolagus cuniculus). World Rabbit Sci 15:23-28

Duszynski DW, Upton SJ, Couch L (1999) The coccidia of the world http://biology.unm.edu/biology/coccidia/lagomorph.html

Foronda PR, Figueruelo EO, Ortega AR, Abreu NA, Casanowa JC (2005) Parasites (viruses, coccidia and helminths) of the wild rabbit (Oryctolagus cuniculus) introduced to Canary Islands from Iberian Peninsula. Acta Parasitol 50:80-84

Gomez-Bautista M, Rojo-Vazquez FA, Alunda JM (1987) The effect of host's age on the pathology of Eimeria stiedae infection in rabbit. Vet Parasitol 24:47-57

Harrenstien L (1999) Gastrointestinal diseases of pet rabbits. Semin Avian Exot Pet 8:83-89

Metwaly MS, Dkhil MA, Gewik MM, Al-Ghamdy AO, Al-Quraishy S (2013) Induced metabolic disturbance and growth depression in rabbits infected with Eimeria coecicola. Parasitol Res 112:31093114

Nosal P, Petryszak A, Nowosad B, Sobolewska M (2006) Pasożyty przewodu pokarmowego królików w badaniach koproskopowych. Wiad Parazytol 52:327-330

Pakandl M (2009) Coccidia of rabbit: a review. Folia Parasitol 56:153-166
Pakandl M, Hlásková L (2007) The reproduction of Eimeria flavescens and Eimeria intestinalis in suckling rabbits. Parasitol Res 101: $1435-1437$

Pakandl M, Hlásková L, Poplštein M, Chromá V, Vodička T, Salát J, Mucksová J (2008) Dependence of the immune response to coccidiosis on the age of rabbit suckling. Parasitol Res 103:1265-1271

Papeschi C, Fichi G, Perrucci S (2013) Oocyst excretion pattern of three intestinal Eimeria species in female rabbits. World Rabbit Sci 21: $77-83$

Połozowski A (1993) Coccidiosis of rabbits and its control. Wiad Parazytol 39:13-28

Regulation (EC) No 854/2004 of the European Parliament and of the Council of 29 April 2004 laying down specific rules for the organisation of official controls on products of animal origin intended for human consumption. http://eur-lex.europa.eu/LexUriServ/ LexUriServ.do?uri=OJ:L:2004:226:0083:0127:EN:PDF

Rinaldi L, Russo T, Schioppi M, Pennacchio S, Cringoli G (2007) Passalurus ambiguus: new insights into copromicroscopic diagnosis and circadian rhythm of egg excretion. Parasitol Res 101: $557-561$

Sadzikowski AB, Szkucik K, Szczepaniak KO, Paszkiewicz W (2008) Występowanie pierwotniaków z rodzaju Eimeria u królików rzeźnych pochodzacych z różnych hodowli. Med Weter 64:1426-1429

Sołtysiak Z, Bednarski M, Piekarska J (2007) Wagrzyca wątroby królika. Med Weter 63:1255-1257

Soveri T, Valtonen M (1983) Endoparasites of hares (Lepus Timidus L. and L. Europaeus Pallas) in Finland. J Wildl Dis 19:337-341

Szkucik K, Paszkiewicz W (2011) Występowanie zmian chorobowych i odchyleń jakościowych w tuszkach królików rzeźnych w Polsce w latach 2000-2010. Med Weter 67:690-693

Yagoob G, Hossein H (2011) Prevalence rate of endoparasites in wild rabbits of East-Azerbaijan Province, Iran. Ann Biol Res 2:31-35 